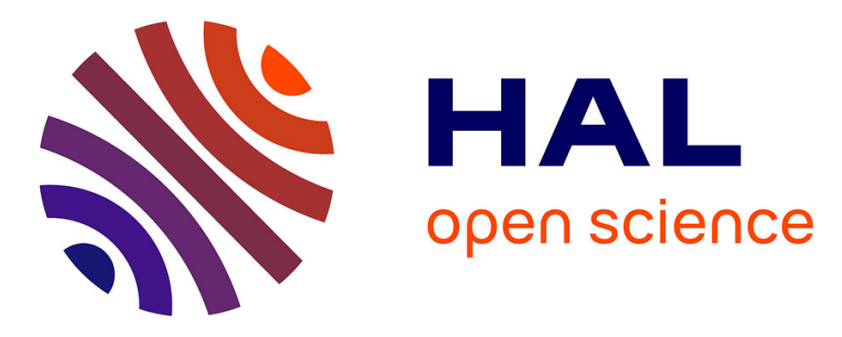

\title{
A study of ${ }^{15} \mathrm{~N}$ transfer between legumes and grasses \\ Florence Paynel, Fabien Lesuffleur, Jacques Bigot, Sylvain Diquélou, Jean-Bernard Cliquet
}

\section{To cite this version:}

Florence Paynel, Fabien Lesuffleur, Jacques Bigot, Sylvain Diquélou, Jean-Bernard Cliquet. A study of ${ }^{15} \mathrm{~N}$ transfer between legumes and grasses. Agronomy for Sustainable Development, 2008, 28 (2), pp.281-290. hal-00886394

\section{HAL Id: hal-00886394 https://hal.science/hal-00886394}

Submitted on 1 Jan 2008

HAL is a multi-disciplinary open access archive for the deposit and dissemination of scientific research documents, whether they are published or not. The documents may come from teaching and research institutions in France or abroad, or from public or private research centers.
L'archive ouverte pluridisciplinaire HAL, est destinée au dépôt et à la diffusion de documents scientifiques de niveau recherche, publiés ou non, émanant des établissements d'enseignement et de recherche français ou étrangers, des laboratoires publics ou privés. 


\title{
Original article
}

\section{A study of ${ }^{15} \mathrm{~N}$ transfer between legumes and grasses}

\author{
Florence PAYNEL ${ }^{1}$, Fabien LESUFFLEUR ${ }^{2}$, Jacques BIGOT ${ }^{2}$, Sylvain DiQUÉLOU ${ }^{2}$, Jean-Bernard CLIQUET ${ }^{2 *}$ \\ ${ }^{1}$ UMR CNRS/INRA/SupAgroM/UMII 5004 B\&PMP, Biochimie and Physiologie Moléculaire des Plantes, IBIP, 2 place Viala, 34060 Montpellier \\ Cedex 1, France \\ ${ }^{2}$ UMR INRA-UCBN 950 EVA, Écophysiologie Végétale, Agronomie et nutritions N,C,S, Université de Caen, 14032 Caen Cedex, France
}

(Accepted 13 December 2007)

\begin{abstract}
The overuse of classical N fertilisers contributes substantially to environmental degradation by pollution of groundwater by nitrates. This leaching of $\mathrm{N}$ in waters is also an economic flaw for farmers because only a part of the fertiliser is used by the plants. Here, systems involving mixtures of legumes and grasses represent a sustainable alternative because legumes can fix atmospheric $\mathrm{N}_{2}$ using symbiotic microbes. $\mathrm{N}$ transfer in those mixtures has been thoroughly investigated but little is known concerning the effect of $\mathrm{N}$ fertiliser on $\mathrm{N}$ transfer between $\mathrm{N}$-fixing legumes and companion grasses. In white clover (Trifolium repens $\mathrm{L}$.) - perennial ryegrass (Lolium perenne L.) associations, $\mathrm{N}$ is transferred mostly through rhizodeposition into the soil by clover followed by re-uptake by ryegrass. Rhizodeposition of $\mathrm{N}$ occurs through senescence and decomposition of legume tissue or through exudation of $\mathrm{N}$ compounds by living cells. Ammonium and amino acids are the main compounds exuded and their exudation is thought to occur by passive diffusion attributed to a concentration gradient from root to soil. In this study, we test the hypothesis that greater $\mathrm{N}$ transfer from clover to grass, as seen in $\mathrm{N}$-rich soils or nutrient solutions, is due to greater $\mathrm{N}$ rhizodeposition brought about by higher ammonium and amino acid content of roots. The relations between $\mathrm{N}$ input, root $\mathrm{N}$ content, $\mathrm{N}$ net exudation and $\mathrm{N}$ transfer between legumes and grasses were investigated using ${ }^{15} \mathrm{~N}$ by growing white clover and perennial ryegrass with increasing $\mathrm{N}$ application in axenic microlysimeters or in pots. Ammonium and amino acid concentrations were measured in root tissues, in root bathing solutions and in soils. We found that mineral $\mathrm{N}$ application strongly reduced atmospheric $\mathrm{N}$ fixation by clover, from 3.0 to 0.9 mg per plant, and root amino acid content, from 164 to 49 nmoles per g dry weight, but had no effect on ammonium and amino acid concentrations in sterile exudates, showing for the first time that amino acid net exudation is independent of root content. In contrast, ammonium and amino acid concentrations in clover soils increased with $\mathrm{N}$ fixation, showing the link between $\mathrm{N}$ fixation and $\mathrm{N}$ rhizodeposition in soils. Nitrate application increased ryegrass root growth by 7-8 times, and transfer of $\mathrm{N}$ between clover and ryegrass (by 3 times). It is concluded that $\mathrm{N}$ fertiliser does not modify $\mathrm{N}$ exudation but decreases $\mathrm{N}$ fixation and ammonium rhizodeposition in soil by clover. $\mathrm{N}$ fertiliser increases $\mathrm{N}$ transfer between clover and ryegrass by increasing soil exploration by ryegrass and giving a better access to different available $\mathrm{N}$ sources, including the $\mathrm{N}$ compounds exuded from clover.
\end{abstract}

\section{INTRODUCTION}

Because use of $\mathrm{N}$ fertiliser contributes substantially to environmental pollution (Deutsch et al., 2006; Umar and Iqbal, 2007), biological alternatives have received increasing attention in the last decades in agricultural practices. Biological nitrogen $(\mathrm{N})$ fixation can act as a sustainable source of $\mathrm{N}$ and can complement or replace fertiliser inputs (Garg and Geetanjali, 2007), and intercropping legumes capable of symbiotic $\mathrm{N}$ fixation offers an economically attractive and ecologically efficient means of reducing $\mathrm{N}$ inputs. Atmospheric $\mathrm{N}$ fixed by legumes is partially exchanged to companion grasses, mainly belowground. The $\mathrm{N}$ transfer from white clover to perennial ryegrass has been assessed at between 11 and $113 \mathrm{~kg} \mathrm{~N} \mathrm{ha}^{-1}$ year $^{-1}$ with a mean of $70 \mathrm{~kg} \mathrm{~N} \mathrm{ha}^{-1}$ year $^{-1}$ (Ledgard and Steele,

* Corresponding author: jean-bernard.cliquet@unicaen.fr
1992; Elgersma et al., 2000). These highly variable results have been attributed to numerous abiotic and biotic factors (Soussana and Hartwig, 1996; Ta and Farris, 1987; Elgersma et al., 2000). Although $\mathrm{N}$ fertilisation strongly reduces $\mathrm{N}$ fixation by clover and the proportion of clovers in swards (Boller and Nösberger, 1987; Høgh-Jensen and Schjoerring, 1997), N fertiliser can increase the proportion of atmospheric $\mathrm{N}$ transferred from the legume to the grass (Høgh-Jensen and Schjoerring, 1997; Elgersma et al., 2000).

Nitrogen can be transferred in plant mixtures through three different pathways (Fig. 1). First, $\mathrm{N}$ transfer between legumes and grasses can occur directly via mycorrhizal fungi interconnecting the root systems of both species and second, indirectly (via the soil compartment) through $\mathrm{N}$ rhizodeposition into the soil followed by uptake by grass (Johansen and Jensen, 1996; Rogers et al., 2001; Høgh-Jensen and Schjoerring, 2001). N rhizodeposition can be due to dead above- and belowground 


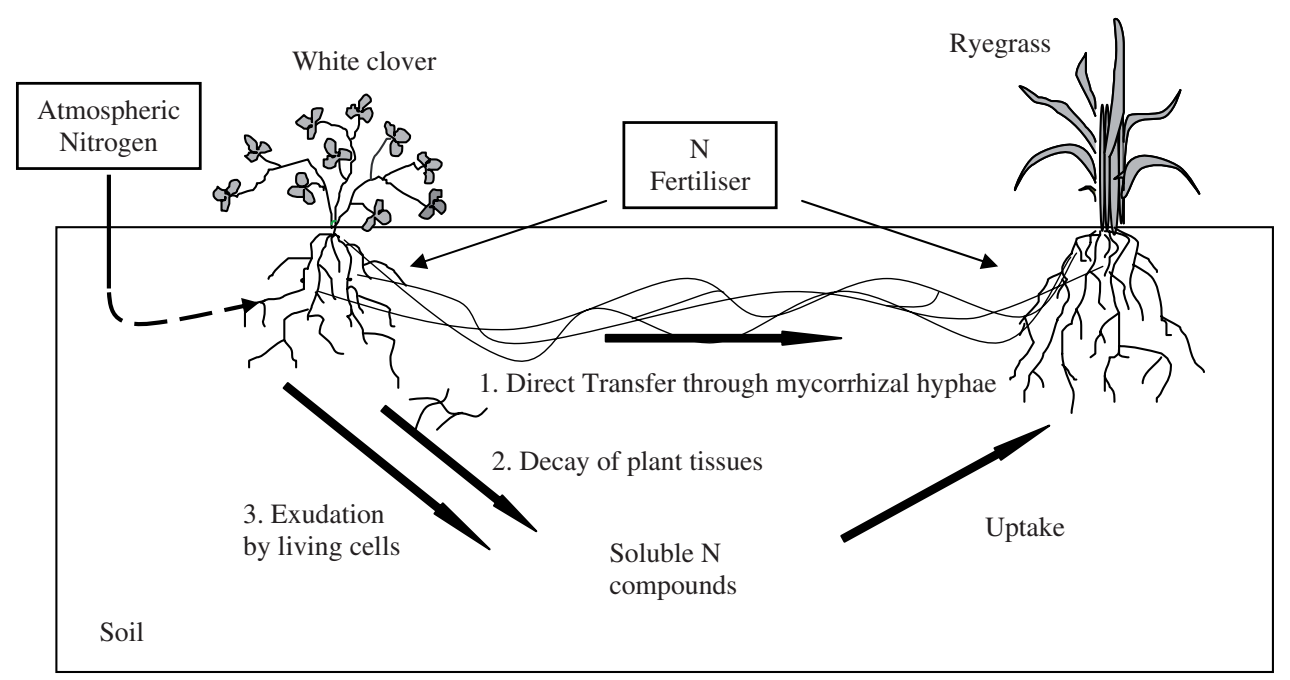

Figure 1. Possible pathways of $\mathrm{N}$ transfer between legumes and grasses. 1. Direct transfer through mycorrhizal hyphae, 2 . Degradation and decay of legume dead tissues or 3 . Nitrogen exudation by living legume cells. $\mathrm{N}$ coming from degradation of plant tissues and from exudation can be taken up by grass in the form of ammonium or amino acids.

plant tissue degradation and turnover processes (Ledgard and Steele, 1992) or to N root exudation (Paynel et al., 2001). The significance of each pathway is still under debate. In a recent study, Rogers et al. (2001) showed that very little $\mathrm{N}$ is transferred directly from clover to ryegrass through arbuscular mycorrhizal fungi interconnecting both plants. In old plants, turnover of $\mathrm{N}$ in root nodules and stolons is thought to be the major source of transferable $\mathrm{N}$ between these two species (Johansen and Jensen, 1996; Høgh-Jensen and Schjoerring, 2001).

$\mathrm{N}$ transfer through exudation by clover roots followed by $\mathrm{N}$ uptake by ryegrass was shown to be a major pathway in young (two-month-old) plants (Paynel et al., 2001; Paynel and Cliquet, 2003). Ammonium and amino acids have been shown to be the major $\mathrm{N}$ compounds exuded by legume roots (Ta et al., 1986; Brophy and Heichel, 1989). Exudation of these compounds is thought to occur by passive diffusion attributed to a concentration gradient from root to soil (Jones and Darrah, 1994; Shepherd and Davies, 1994), but little is known concerning exudation of ammonium and amino acids from legume roots (Ta et al., 1986; Brophy and Heichel, 1989).

In the present study, we test the hypothesis that greater $\mathrm{N}$ transfer from clover to grass, as seen in N-rich soils or nutrient solutions, is due to greater $\mathrm{N}$ rhizodeposition brought about by higher amino acid and ammonium content of roots.

Various contents of amino acid and ammonium in roots were obtained by growing plants on different $\mathrm{N}$ concentrations. Ammonium and amino acids were quantified in sterile root exudates and in soils and ${ }^{15} \mathrm{~N}$ was used to quantify $\mathrm{N}$ transfer between species. In a first experiment we chose to use the ${ }^{15} \mathrm{~N}$ dilution technique to measure $\mathrm{N}$ transfer (Paynel et al., 2001). Plants were grown in sand in microlysimeters, because this system allows harvest of $\mathrm{N}$ compounds released by plants, without interference with soil (Shepherd and Davies, 1994; Paynel et al., 2001). This experiment was conducted under axenic conditions in order to prevent release and/or consumption of $\mathrm{N}$ compounds by microbial populations. Because rhizodeposition of $\mathrm{N}$ by legumes occurs not only through exudation but also through decomposition of legume tissue and cell lysis, another experiment was performed in soil to analyse the effect of $\mathrm{N}$ input and $\mathrm{N}$ fixation on $\mathrm{N}$ rhizodeposition on a longer time-scale. Ammonium and amino acid concentration profiles in soil supporting perennial ryegrass or white clover were compared to study the effect of $\mathrm{N}$ rhizodeposition on $\mathrm{N}$ pools in soil.

\section{MATERIALS AND METHODS}

\subsection{Microlysimeter experiment}

Seeds of white clover (Trifolium repens L.) cv. Grasslands Huia and perennial ryegrass (Lolium perenne L.) cv. Bravo were surface-sterilised with, successively, $95 \% \mathrm{H}_{2} \mathrm{SO}_{4}$ for 30 seconds, $95 \%$ ethanol for 5 minutes and $10 \% \mathrm{H}_{2} \mathrm{O}_{2}$ for 30 minutes (Benizri et al., 1995). The seeds were rinsed in sterile demineralised water and germinated in Petri dishes containing a nutrient agar $0.5 \%$ medium, derived from Murashige and Skoog medium (1962). Ryegrass seeds were germinated three weeks later than clover to achieve comparable sized plants. Two weeks after germination, plants were transferred to individual microlysimeters which were constructed from a $60 \mathrm{~mL}$ volume syringe containing $100 \mathrm{~g}$ of sterilised sand as the growth medium. Clover plants were inoculated with $1 \mathrm{~mL}$ of Rhizobium trifolii (T354) in agar solution. The plant tops were allowed to grow in the normal atmosphere, whereas the roots were grown in an axenic sand culture (Paynel et al., 2001). The plants were then kept in a controlled environment room at $20 / 15{ }^{\circ} \mathrm{C}$ day/night with a $16 \mathrm{~h}$ photoperiod and a photosynthetically active radiation (PAR) flux of $300 \mu \mathrm{mol} \mathrm{m}^{-1} \mathrm{~s}^{-1}$ at plant level. 
Plants of clover and control ryegrass were grown individually in microlysimeters (Paynel et al., 2001). Sterile autoclaved nutrient solution containing $0.1,0.5,1$ or $2 \mathrm{mM}$ $\mathrm{K}^{15} \mathrm{NO}_{3}(5$ atom \%) was prepared and $10 \mathrm{~mL}$ were added to the plants three times per week (days 1, 3 and 5). The volume of the leachate averaged $9 \mathrm{~mL}$, and the total volume of solution surrounding each plant averaged $23.5 \mathrm{~mL}$. Half of this solution containing nutrient solution and exudates from clover went to receiver ryegrass and half was used for analysis. Exudates were collected from receiver ryegrass twice a week by adding $10 \mathrm{~mL}$ of sterilised nutrient solution without $\mathrm{N}$ (days 2 and 4). Each treatment consisted of five replicates of two microlysimeters with one plant in each. Sterile water was added daily to maintain an average sand water content of $25 \%$ for ryegrass and clover. Exudates of the same week were bulked together before analysis. An aliquot of the exudates was used to count the bacterial population present in the microlysimeters by culturing them in a nutrient agar $1.5 \%$ (Sigma) plate. No bacteria were found in the sterile exudate. The exudate samples were frozen immediately after collection, freeze-dried, redissolved in $1.5 \mathrm{~mL}$ of ultra-pure water and filtered through a $0.45 \mu \mathrm{m}$ filter before quantification of ammonium and amino acids. Plants were harvested when the clover was 87 days old and the ryegrass 69 days old. The clover plants were separated into shoots (stolons and leaves) and roots and the ryegrass plants into shoots and roots. All of the plant components were freeze-dried, weighed and analysed for total $\mathrm{N}$ and ${ }^{15} \mathrm{~N}$ content.

\subsection{Pot experiment}

This experiment was designed to determine the effect of ammonium and amino acid net exudation by clover on the content of these compounds in the soil, and to determine the effect of $\mathrm{N}$ fixation by clover on $\mathrm{N}$ rhizodeposition in soil. Topsoil (5 to $20 \mathrm{~cm}$ depth) was collected from a LoliumCynosurus grassland sward located in Le Haras du Pin, Normandy, France, with perennial ryegrass the predominant grass species and white clover the predominant forb. The soil was a silty sandy loam $\left(\mathrm{pH} \mathrm{H}_{2} 0,6.0\right.$, Organic $\mathrm{C}, 2.7 \%$, Total $\mathrm{N}$, $0.35 \%$ ). Soil was removed and stored in polypropylene bags for immediate transport back to the laboratory, where it was sieved $(<2 \mathrm{~mm})$ to homogenise its structure and eliminate small roots and litter, then stored at $4{ }^{\circ} \mathrm{C}$. Seedlings were prepared as in the microlysimeter experiment. Two weeks after germination, eight plants of clover, eight plants of ryegrass, or four plants of each species were transferred into $1755 \mathrm{~mL}$ pots, (depth $10 \mathrm{~cm}$, mean diameter $12.5 \mathrm{~cm}$ ), containing a sufficient quantity of soil to obtain the same soil bulk density as measured in the parent grassland, i.e. $0.9 \mathrm{~kg} \mathrm{dm}^{-3}(=1580 \mathrm{~g}$ of dry soil). At the beginning of the experiment, plants were supplied with deionised water and nutrient solution to achieve both $30 \%$ soil water content and ammonium nitrate concentrations equivalent to 0 (unfertilised), 50 or $180 \mathrm{~kg} \mathrm{~N} \mathrm{ha}^{-1}$. Pots were watered daily and brought back to initial weight with a sufficient amount of deionised water every two days to maintain initial soil humidity. Three control pots of the lower and three of the higher $\mathrm{N}$ treatments were established without any plants in order to study plant effects on soluble $\mathrm{N}$ profiles of the soil. Sixty days after transplanting, four replicate pots for each treatment were harvested. Plants were harvested and the soil was homogenised and stored for less than 48 hours at $4{ }^{\circ} \mathrm{C}$. Soil water content was determined by drying at $60{ }^{\circ} \mathrm{C}$ for at least $48 \mathrm{~h}$. Because of the high root density throughout the soil, no differentiation was made between rhizosphere soil and bulk soil and we defined the whole harvested soil as rhizosphere soil. Exudates from duplicate samples of $10 \mathrm{~g}$ soil from each of the pots were extracted in $50 \mathrm{~mL} \mathrm{KCl} 0.5 \mathrm{M}$ according to Jones et al. (2002). Preliminary experiments were performed to compare extraction of $\mathrm{N}$ compounds in $0.5 \mathrm{M}$ or $1 \mathrm{M} \mathrm{KCl}$ and gave similar results, but $1 \mathrm{M} \mathrm{KCl}$ proved to be too concentrated for HPLC analysis.

\section{3. $\mathbf{N}$ fixation and $\mathbf{N}$ transfer quantification}

Total $\mathrm{N}$ and ${ }^{15} \mathrm{~N}$ were determined by Isotope Ratio Mass Spectrometry (Europa 20/20 IRMS, Europa Scientific, Crewe, UK.). The ${ }^{15} \mathrm{~N}$ isotope dilution technique allows determination of the percentage of $\mathrm{N}$ in the plant parts derived from the atmosphere (\% Ndfa); (Paynel et al., 2001):

For clover, it can be evaluated from the following equation: $\% \mathrm{Ndfa}=\left[1-\left(\%{ }^{15} \mathrm{~N}\right.\right.$ atom excess in clover $/$

$\%{ }^{15} \mathrm{~N}$ atom excess in control grass) $] \times 100$

where control grass is the ryegrass grown independently of the clover.

The proportion of ryegrass $\mathrm{N}$ derived from fixation by clover and transferred to ryegrass was calculated with the similar principle:

$\% \mathrm{Ndfa}=\left[1-\left(\%{ }^{15} \mathrm{~N}\right.\right.$ atom excess in grass in mixture $/$ $\%{ }^{15} \mathrm{~N}$ atom excess in control grass) $] \times 100$.

\subsection{Exudate analysis}

Nitrate and ammonium contents were measured using a continuous-flow analyser (Bran+Luebbe, Noderstedt, Germany). Nitrate was measured by reduction to nitrite on a column of cadmium at $\mathrm{pH}$ 8. Nitrite reacted with sulphanilamide, $\mathrm{N}$-1-naphthylethylene-diamine dihydrochloride. The buffered solution containing ammonium reacted with salycilate $8 \%(\mathrm{w} / \mathrm{v})$ and dichloro-isocyanurate $0.18 \%(\mathrm{w} / \mathrm{v})$. The amino acids were quantified by HPLC as $o-$ phthaldialdehyde derivatives on a C-18 column using a Beckmann 32Karat system and a fluorimeter (Beckmann Instruments, San Ramon, Ca, USA). This method does not allow the quantification of proline. The internal standard was $\alpha$-aminobutyric acid and the gradient was produced using two eluents: $50 \mathrm{mM}$ sodium acetate buffer, $\mathrm{pH} 5.9$ with $200 \mathrm{~mL} \mathrm{~L}^{-1}$ methanol and $100 \%$ methanol.

\subsection{Statistical analysis}

In the microlysimeter experiment, each treatment had five replicates, and each replicate consisted of two independent 
Table I. Effect of potassium nitrate $\left(\mathrm{KNO}_{3}\right)$ concentration of the nutrient solution on plant growth (expressed as mg dry weight plant $\left.{ }^{-1}\right)$, total $\mathrm{N}$ (expressed as $\mathrm{mg} \mathrm{N}$ plant ${ }^{-1}$ ) and amount of $\mathrm{N}$ (expressed as $\mathrm{mg} \mathrm{N}$ plant ${ }^{-1}$ ) coming from the atmosphere for 87 day-old clover grown in microlysimeters. Data are means ( \pm standard error) of five independent replicates and each replicate consisted of two plants grown in individual microlysimeters. Clover growth and total $\mathrm{N}$ were not affected by the $\mathrm{N}$ content of the nutrient solution, but $\mathrm{N}$ fixation decreased strongly with increasing nitrate concentration in the nutrient solution.

\begin{tabular}{ccccc}
\hline $\begin{array}{c}\text { Nitrate concentration of the } \\
\text { nutrient solution }\end{array}$ & $\begin{array}{c}\text { Dry weight } \\
\left(\mathrm{mg} \mathrm{plant}^{-1}\right)\end{array}$ & $\begin{array}{c}\text { Total N } \\
\left(\mathrm{mg} \mathrm{N} \mathrm{plant}^{-1}\right)\end{array}$ & $\begin{array}{c}\text { N derived from the atmosphere } \\
\left.\text { (mg N plant }^{-1} \text { for clover }\right)^{-}\end{array}$ \\
\hline Clover & $0.1 \mathrm{mM}$ & $95 \pm 16$ & $3.3 \pm 0.6$ & $3.0 \pm 0.6$ \\
& $0.5 \mathrm{mM}$ & $77 \pm 12$ & $2.3 \pm 0.3$ & $1.6 \pm 0.2$ \\
& $1 \mathrm{mM}$ & $102 \pm 27$ & $2.8 \pm 0.7$ & $1.6 \pm 0.4$ \\
$2 \mathrm{mM}$ & $83 \pm 12$ & $2.7 \pm 0.4$ & $0.9 \pm 0.1$ \\
\hline
\end{tabular}

plants grown in individual microlysimeters. In the pot experiment each treatment had four replicates. Data were analysed by ANOVA (Minitab, version 13.20) after data normality was checked by Ryan-Joiner tests $(95 \%)$ and equality of variances by Levene tests $(95 \%)$. Means were compared (Tukey's Honestly Significant Differences Method) when a treatment effect occurred significantly. Data which did not realise parametric conditions were analysed by Kruskal Wallis tests. Medians were compared using the Median Mood test when a treatment effect occurred significantly. Pearson correlation was used to assess the strength of the linear relationship between amino acid root content and concentration in the nutrient solution.

\section{RESULTS AND DISCUSSION}

\subsection{Nitrate application reduces nitrogen fixation by white clover and amino acid content in roots}

Nitrogen fixation was measured in both experiments and amino acid and ammonium contents in roots were measured in the microlysimeter experiment to study the effect of $\mathrm{N}$ fixation on these contents. In the microlysimeter experiment, clover growth and total $\mathrm{N}$ were not affected by the $\mathrm{N}$ content of the nutrient solution (Tab. I). N fixation by clover in microlysimeters decreased strongly with increasing nitrate concentration in the nutrient solution. The amount of $\mathrm{N}$ derived from the atmosphere in clover declined from $3.0 \mathrm{mg} \mathrm{N}$ plant $^{-1}$ for the $0.1 \mathrm{mM}$ treatment to $0.9 \mathrm{mg} \mathrm{N}$ plant $^{-1}$ for the $2 \mathrm{mM}$ treatment. Expressed as a percentage, this atmospheric $\mathrm{N}$ decreased, respectively, from $92.7 \%$ of total $\mathrm{N}$ to $33.1 \%$ of total $\mathrm{N}$. In the soil experiment, the amount of $\mathrm{N}$ derived from the atmosphere in clover also declined significantly $(\mathrm{H}=21.68, P<0.001)$ with increasing $\mathrm{N}$ input, and was higher in intercropped clover compared with pure stands $(\mathrm{H}=11.52, P=0.001)$.

This decrease in $\mathrm{N}$ fixation led to a small increase in ammonium and a drastic decrease in total free amino acids in clover roots, as shown in Table II. Asparagine was the most abundant amino acid in clover roots, and its content decreased with increasing nitrate concentration in the nutrient solution from $96.7 \mu \mathrm{mol} \mathrm{g}^{-1}$ dry weight for the $0.1 \mathrm{mM}$ treatment to $11.6 \mu \mathrm{mol} \mathrm{g}{ }^{-1}$ dry weight for the $1 \mathrm{mM}$ and the $2 \mathrm{mM}$ treatments.

This inhibition of $\mathrm{N}$ fixation by inorganic $\mathrm{N}$ observed here in hydroponic and soil cultures has been previously observed
Table II. Effect of potassium nitrate $\left(\mathrm{KNO}_{3}\right)$ concentration of the nutrient solution on ammonium content (expressed as $\mathrm{mM} \mathrm{g}^{-1}$ dry weight) and free amino acid content (expressed as $\mu \mathrm{M} \mathrm{g}^{-1}$ dry weight) of roots of 87 day-old white clover grown in microlysimeters. Data are means \pm standard error of five independent replicates and each replicate consisted of two plants grown in individual microlysimeters. The decrease in $\mathrm{N}$ fixation due to high nitrate concentration of the nutrient solution led to a small increase in ammonium and a drastic decrease in total free amino acid content in clover roots. Asparagine, the most abundant amino acid in clover roots, is well representative of this decrease. This shows that production of asparagine is strongly related to $\mathrm{N}$ fixation in clover.

\begin{tabular}{lcrrr}
\hline & $0.1 \mathrm{mM}$ & $0.5 \mathrm{mM}$ & \multicolumn{1}{c}{$1 \mathrm{mM}$} & \multicolumn{1}{c}{$2 \mathrm{mM}$} \\
\hline Ammonium & $3.1 \pm 0.8$ & $3.4 \pm 0.6$ & $4.1 \pm 1.8$ & $7.8 \pm 1.2$ \\
Aspartate & $13.9 \pm 1.5$ & $8.4 \pm 2.0$ & $4.7 \pm 0.4$ & $5.0 \pm 0.3$ \\
Glutamate & $13.3 \pm 2.3$ & $5.9 \pm 2.0$ & $6.8 \pm 0.7$ & $6.5 \pm 0.5$ \\
Asparagine & $96.7 \pm 15.6$ & $42.1 \pm 8.8$ & $11.6 \pm 1.6$ & $11.6 \pm 1.6$ \\
Glutamine & $8.4 \pm 1.4$ & $6.3 \pm 1.7$ & $1.6 \pm 0.2$ & $1.2 \pm 0.0$ \\
Serine & $10.3 \pm 1.6$ & $5.1 \pm 0.8$ & $3.3 \pm 0.3$ & $3.0 \pm 0.2$ \\
Glycine & $7 \pm 1.3$ & $11.7 \pm 1.2$ & $2.0 \pm 0.3$ & $3.0 \pm 0.4$ \\
Others & $14.3 \pm 2.9$ & $6.6 \pm 2.1$ & $19.5 \pm 4.5$ & $18.4 \pm 5.1$ \\
Total Amino acids & $163.9 \pm 25.4$ & $86.1 \pm 18.5$ & $49.6 \pm 8.0$ & $48.8 \pm 8.2$ \\
\hline
\end{tabular}

by numerous authors (Ledgard and Steele, 1992; Høgh-Jensen and Schjoerring, 1997) and is explained by a decrease in nodule production and nitrogenase activity (Svenning et al., 1996). Asparagine has been shown to be a major product of $\mathrm{N}$ fixation in temperate legumes (White et al., 2007) and our data show that its content is strongly related to $\mathrm{N}$ fixation.

\section{2. $\mathbf{N}$ net exudation in axenic culture is independent of root content and nitrogen fixation}

To investigate the relation between root content and root exudation, ammonium and amino acids were measured in root exudates (microlysimeter experiment). The concentration of ammonium and amino acids in sterile root exudates is the result of exudation of these compounds and uptake by roots. Receiver ryegrass was fed throughout the microlysimeter experiment with exudates from donor clover, and control ryegrass was fed with the same nutrient solution as clover. The exudates were collected three times per week to avoid accumulation of $\mathrm{N}$ compounds in exudates. No detectable amounts of these compounds were measured in the sterile nutrient solution used for exudate collection. As no microorganisms were 


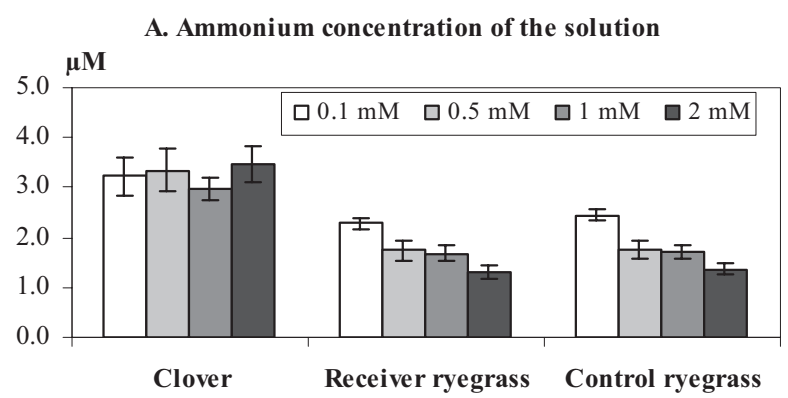

B. Amino acid concentration of the solution

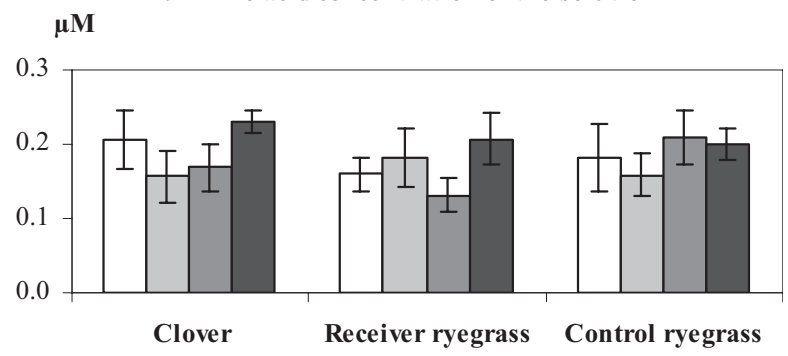

Figure 2. Effect of potassium nitrate $\left(\mathrm{KNO}_{3}\right)$ concentration of the nutrient solution on concentration of ammonium (A) and total amino acids (B) in the solution surrounding roots of clover, control ryegrass and receiver ryegrass. Exudates were collected three times a week. Each value is the average concentration of ammonium and amino acids in the solution surrounding the roots over the experimental period, from day 47 to day 87 for clover, and from day 29 to day 69 for ryegrass. Data are means ( \pm standard error) of five independent replicates and each replicate consisted of two plants grown in individual microlysimeters. Ammonium concentration in the root bathing solution of clover was not significantly modified by increasing nitrate concentration of the nutrient solution, but decreased in the root bathing solution of ryegrass. No effect of $\mathrm{N}$ application on the amounts of total amino acids exuded was observed throughout the experiment for clover or ryegrass.

found in these axenic microlysimeters, it can be deduced that these compounds were released only by plant roots. The results shown in Figure 2 are expressed as the mean concentration of ammonium and amino acids in the solution surrounding the roots during the experimental period (average volume of $23.5 \mathrm{~mL}$ ). The nitrate concentration of the root bathing solution was higher than ammonium and amino acid concentrations for all treatments, because this ion was provided in the nutrient solution (data not shown). Clover exuded significantly more ammonium than ryegrass $(\mathrm{H}=29.30$, $P<0.001)$. Ammonium concentration in the root bathing solution of clover was not significantly modified by increasing the nitrate concentration of the nutrient solution and ranged from $3.0 \pm 0.2 \mu \mathrm{M}$ for the $1 \mathrm{mM}$ treatment to $3.5 \pm 0.4 \mu \mathrm{M}$ for the $2 \mathrm{mM}$ treatment (Fig. 2A). This concentration was also independent of plant age, varying between $2.8 \pm 0.2 \mu \mathrm{M}$ and 3.7 $\pm 0.25 \mu \mathrm{M}$ for 47 day-old and 82 day-old clover, respectively. Expressed in quantities, the average daily rate was 29 nmoles of ammonium exuded per plant of clover per day. No relationship was observed for clover between ammonium content and ammonium net exudation, as the increase in ammonium content, caused by increased $\mathrm{N}$ application, did not lead to a modification of ammonium net exudation. In contrast, ammonium concentration in the root bathing solution of receiver and control ryegrass decreased significantly $(\mathrm{H}=11.07, P<0.05)$ with increasing nitrate concentration of the nutrient solution, showing an increase in ammonium uptake by ryegrass with increasing nitrate concentration of the nutrient solution. Similarly, measurement of nitrate concentration in clover exudates applied to ryegrass and receiver ryegrass exudates demonstrates that nitrate uptake by ryegrass increases with nitrate concentration of the nutrient solution (data not shown).

The concentrations of the total amino acids in exudates were at much lower levels than ammonium (Fig. 2B) and did not vary for plants aged from 47 to 75 days $(152 \pm 42 \mathrm{nM}$ and $117 \pm 20 \mathrm{nM}$, respectively). The average daily rate was 2.3 nmoles of amino acids exuded per plant of clover per day. No effect of $\mathrm{N}$ application on the amounts of total amino acids exuded was observed throughout the experiment. The same observation was obtained for ryegrass. Figure 3 shows the percentage composition of amino acids found in clover and receiver ryegrass root exudates. In all cases, glycine and serine were the two major amino acids detected, representing, respectively, $33 \% \pm 4 \%$ and $19 \% \pm 1 \%$ of total amino acids exuded for clover and $33 \% \pm 4 \%$ and $19 \% \pm 2 \%$ for ryegrass. Glutamate, aspartate, tyrosine and asparagine were also recovered in the solution, while all other amino acids, including alanine, valine, arginine, glutamine, methionine, phenylalanine, leucine, isoleucine and lysine each constituted less than 5\% of amino acids recovered. The $\mathrm{N}$ concentration of the nutrient solution did not affect the percentage composition of the amino acids exuded. A significant linear relationship between root amino acid content and nutrient solution concentration was observed for asparagine $\left(\mathrm{r}^{2}=0.897, P<0.001\right)$, but no significant correlation was observed between glycine, serine or glutamate content in the roots and in the solution. This shows that the concentration of most of the amino acids of the root bathing solution is independent of root content, except for asparagine.

The ammonium and amino acid pools of root bathing solutions result from influx and efflux at the root-solution interface (Phillips et al., 2004). Our data show that $\mathrm{N}$ net exudation by clover is independent of both $\mathrm{N}$ fixation and ammonium content in roots. The results concerning ammonium are surprising, as Ta et al. (1986) have suggested that ammonium exuded by alfalfa originates from recent $\mathrm{N}$ fixation. However, non-fixing plants such as ryegrass (Fig. 2A: control ryegrass) or maize (Volk, 1995) also release ammonium. Comparison of ammonium concentration in clover exudates applied to receiver ryegrass and ammonium concentration in receiver ryegrass exudates demonstrates that increasing nitrate concentration in the nutrient solution resulted in a higher net uptake of ammonium by ryegrass.

We have shown recently that high proportions of glycine and serine in root bathing solutions observed here or in previous studies (Shepherd and Davies, 1994; Hertenberger and Wanek, 2004) result from a high efflux (Lesuffleur et al., 2007). Influx is energy-dependent and amino acids, and particularly glycine, are taken up actively by plant roots even under field conditions (Streeter et al., 2000; Näsholm et al., 2001; Thornton and Robinson, 2005). Reports on Zea mays (Jones 


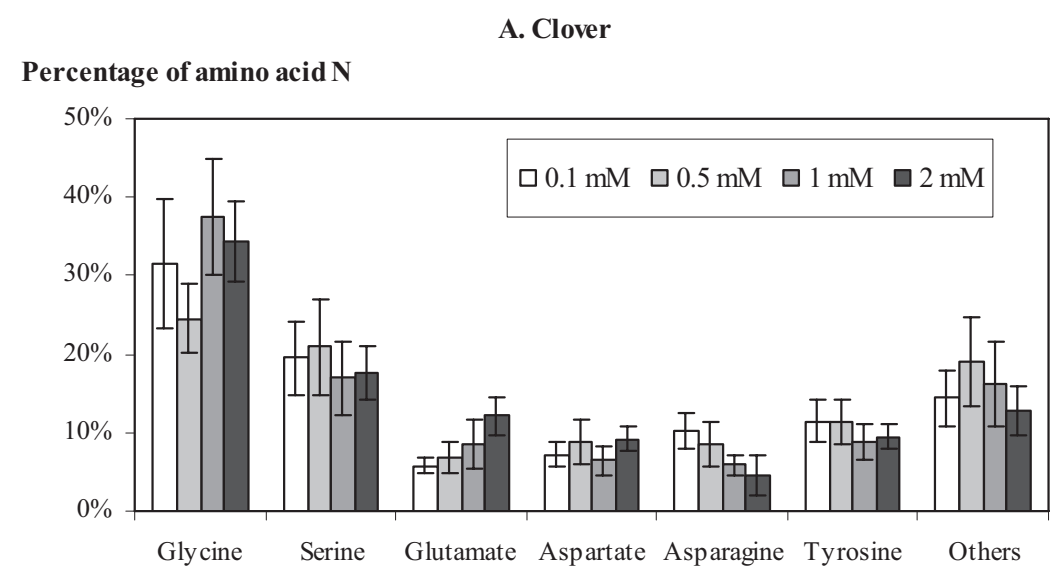

B. Receiver Ryegrass

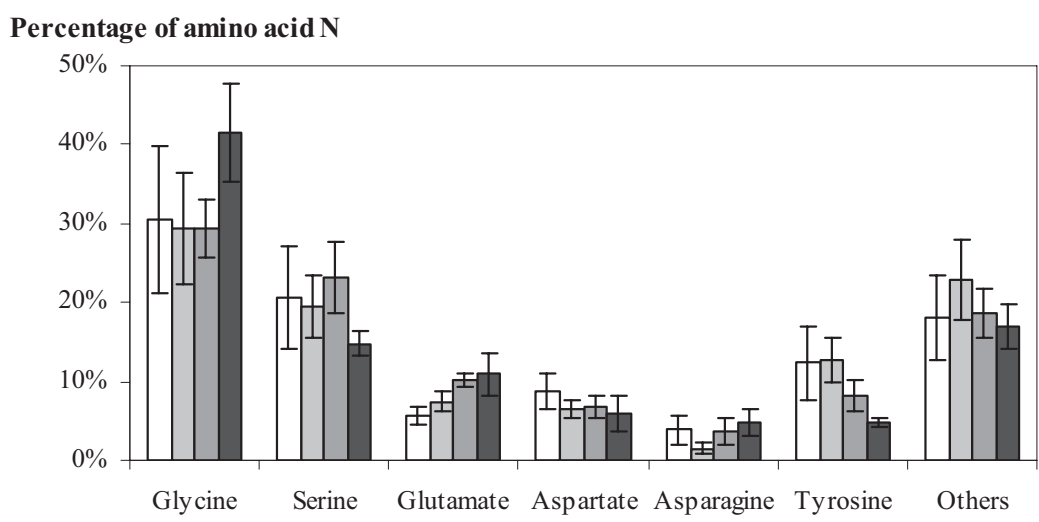

Figure 3. Individual amino acid $\mathrm{N}$ as $\%$ of total free amino acids of root exudates collected from clover (A) or receiver ryegrass (B) grown on increasing concentration of potassium nitrate $\left(\mathrm{KNO}_{3}\right)$ in the nutrient solution. Exudates were collected three times a week. Each value is the average percentage of amino acid $\mathrm{N}$ in exudates collected over the experimental period, from day 47 to day 87 for clover, and from day 29 to day 69 for ryegrass. Data are means ( \pm standard error) of five independent replicates and each replicate consisted of two plants grown in individual microlysimeters. The concentration of most of the amino acids of the root bathing solution was independent of root content, except for asparagine.

and Darrah, 1994), Brassica napus (Shepherd and Davies, 1994), and Triticum aestivum (Rroço et al., 2002) have suggested that the efflux component is a passive process. However, our data show that concentrations of ammonium and major amino acids found in exudates (glycine and serine) are independent of the concentration gradient between root content and root bathing solution. Our finding supports the hypothesis that plant roots could regulate ammonium and amino acid fluxes at the root-soil interface. More generally, there is now evidence that roots can regulate rhizosphere $\mathrm{C}$ flow (Jones et al., 2004) and numerous studies have established the impact of root exudation on soil microbial communities (Nguyen, 2003). As well as sugars, amino acids were the C substrates found to be responsible for the discrimination between microbial communities of ryegrass and clover rhizospheres (Grayston et al., 1998).

\subsection{Ammonium and amino acid concentrations in soil solution increase with $\mathbf{N}$ fixation}

The soil experiment was designed to study the effect of $\mathrm{N}$ input and $\mathrm{N}$ fixation on $\mathrm{N}$ rhizodeposition by clover. We hypothesised that $\mathrm{N}$ rhizodeposition through $\mathrm{N}$ exudation or through $\mathrm{N}$ release from belowground plant debris can increase ammonium concentration in soil and increase the proportion of amino acids such as glycine and serine, previously recovered in root sterile exudates. Nitrate, ammonium and amino acids were measured in the bare soil and in the rhizospheric soils from clover, ryegrass or clover-ryegrass mixture.

When no ammonium nitrate was added to the soil, nitrate concentration averaged $2.5 \pm 0.9 \mathrm{mM}$ at the end of the culture and was not significantly different between soils which had supported clover, ryegrass or the mixture. For the high $\mathrm{N}$ treatment $\left(180 \mathrm{~kg} \mathrm{~N} \mathrm{ha}^{-1}\right)$, the nitrate concentration was higher when clover had been grown in the pot than when ryegrass or the mixture had been grown, as shown in Figure 4A, probably because this ion is taken up more efficiently by ryegrass (Elgersma et al., 2000). The ammonium concentration of the rhizospheric soil was generally lower than the nitrate concentration and was dependent on plant species and $\mathrm{N}$ fertilisation rate (Fig. 4B). Ammonium and amino acid concentrations were much higher than those observed in the sterile solution experiment. As expected, the ammonium concentration 


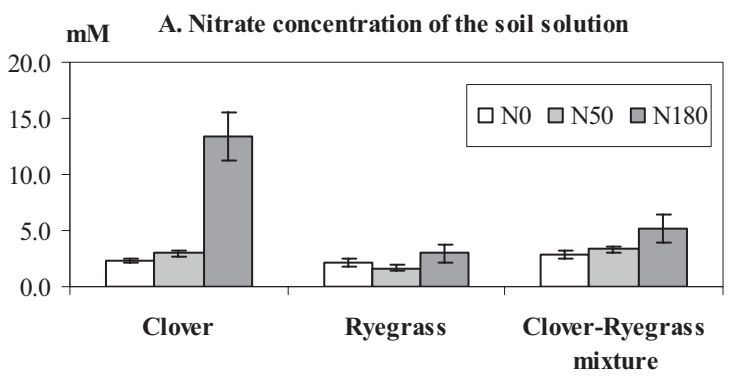

mM B. Ammonium contcentration of the soil solution
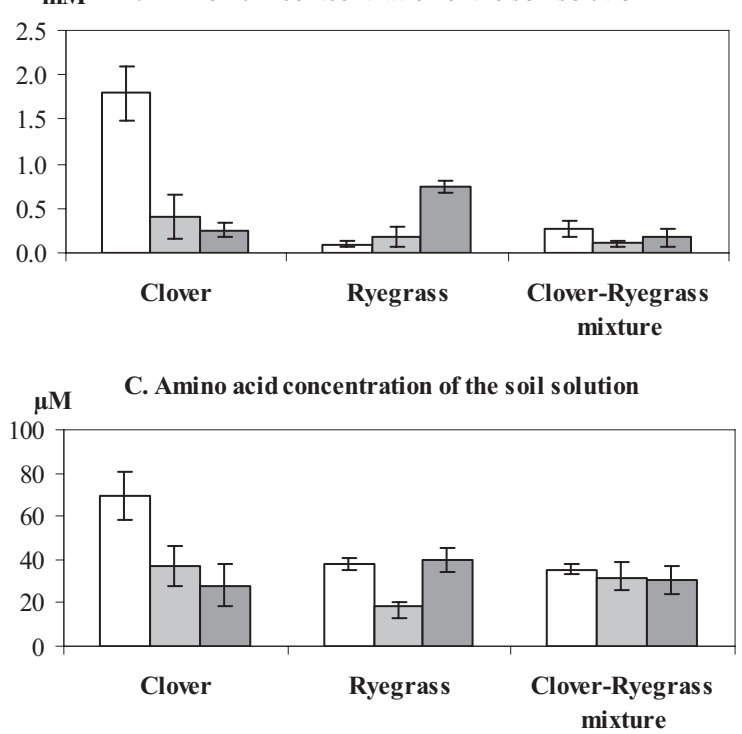

Figure 4. Effect of $\mathrm{N}$ fertilisation rate on concentration of nitrate (A), ammonium (B) and total free amino acids (C) in the rhizosphere soil solution of clover, ryegrass or clover - ryegrass mixture. Data are means ( \pm standard error) of four independent replicate pots of eight plants each. N0: no fertilisation; N50: $50 \mathrm{~kg} \mathrm{~N} \mathrm{ha}^{-1}$; N180: $180 \mathrm{~kg}$ $\mathrm{N} \mathrm{ha}^{-1}$. The highest ammonium and amino $\mathrm{N}$ concentrations in soil were found for clover grown without $\mathrm{N}$ input.

increased like nitrate with the ammonium nitrate fertilisation rate in the ryegrass rhizosphere $(\mathrm{H}=7.53, P<0.05)$. However, it is noteworthy that this concentration decreased with the fertilisation rate in the clover rhizosphere $(\mathrm{H}=6.04$, $P<0.05)$, and remained low when both species were grown together.

Amino acid concentration was less affected than ammonium concentration by treatments, but the highest concentration was observed in the rhizosphere of clover grown with the low $\mathrm{N}$ treatment (Fig. 4C). When no plants were grown in the pot, the concentration of free amino acids in the soil extracts averaged $32.1 \pm 13.1 \mu \mathrm{M}$ and was independent of $\mathrm{N}$ treatment. Little effect of the $\mathrm{N}$ nutrition on the amino acid composition of soil was observed, and the average percentage composition of amino acid $\mathrm{N}$ for all $\mathrm{N}$ treatments is shown in Figure 5. These profiles were close to those observed in the sterile nutrient solution, but higher proportions of asparagine and arginine were observed in the soil solution than in the sterile nutrient solution. Glycine, serine and glutamate were the major amino acids found in the soil solution, while aspartate, asparagine and arginine were also recovered in significant amounts. Alanine, valine, glutamine, methionine, phenylalanine, leucine, isoleucine and lysine were only recovered as traces. Comparison of the free amino acid profiles of bare soil and soils from clover, ryegrass or the mixture shows that the two main amino compounds influenced by the presence of the roots are arginine and asparagine. The asparagine proportion was higher in the rhizospheric soils than in bare soil $(\mathrm{H}=18.25 P<0.001)$, (Fig. 4).

These data confirm previous results (Hertenberger et al., 2002) showing that plant species affect the concentration of free amino acids in soil and show that $\mathrm{N}$ fixation by clover could also affect amino acid profiles in soils. High proportions of glycine, serine and glutamate have also been observed in soil extracts in previous studies (Kielland, 1995; Lipson et al., 1999). The soil amino acid pool is derived from proteolytic rates, microbial and plant uptake (Lipson et al., 2001). Similar profiles observed in axenic exudates (Fig. 3) and soil solutions (Fig. 5) suggest that root net exudation could also have an impact on this pool. However, no direct conclusions can be made as these three major amino acids were also recovered in the bare soil (where no plant roots were present in the pot). High proportions of asparagine in the rhizosphere of clover and ryegrass cannot be explained by $\mathrm{N}$ net exudation by these species, since the proportion of this amide is very low in sterile exudates, but could be the result of rhizodeposition of organic $\mathrm{N}$ through senescence and cell lysis of roots and nodules. This is in agreement with the results of Hertenberger et al. (2002), showing a high proportion of asparagine in the rhizosphere of another plant, Centaurea jacea, storing this amide in roots.

Results from this experiment confirm other studies showing that the presence of Trifolium species in grasslands increases $\mathrm{N}$ availability in soils. High ammonium concentrations in rhizospheric soils of other Trifolium species have been observed by Thomas and Bowman (1998). This result contrasts with the axenic experiment where ammonium concentration in the nutrient solution was independent of $\mathrm{N}$ fertilisation. The similar decrease in ammonium and $\mathrm{N}$ fixation suggests that $\mathrm{N}$ fixation could be a source of ammonium for the soil but the high ammonium concentration observed in the rhizospheric soil of clover grown on a low level of $\mathrm{N}$ could also be explained by a lower ammonium uptake because of high $\mathrm{N}$ fixation. Biological $\mathrm{N}$ fixation can act as a sustainable source of $\mathrm{N}$ and is the major source of $\mathrm{N}$ for most terrestrial ecosystems (Garg and Geetanjali, 2007), but the present soil study shows that $\mathrm{N}$ fertiliser decreases $\mathrm{N}$ input from biological fixation, through decreasing $\mathrm{N}$ fixation and ammonium rhizodeposition. It must be added that $\mathrm{N}$ fertiliser also reduces the proportion of clover in grasslands (Boller and Nösberger, 1987; Høgh-Jensen and Schjoerring, 1997).

\subsection{Nitrate application increases $\mathbf{N}$ transfer between clover and ryegrass}

In order to study the effect of $\mathrm{N}$ input on $\mathrm{N}$ transfer between clover and ryegrass, receiver ryegrass was fed throughout the 


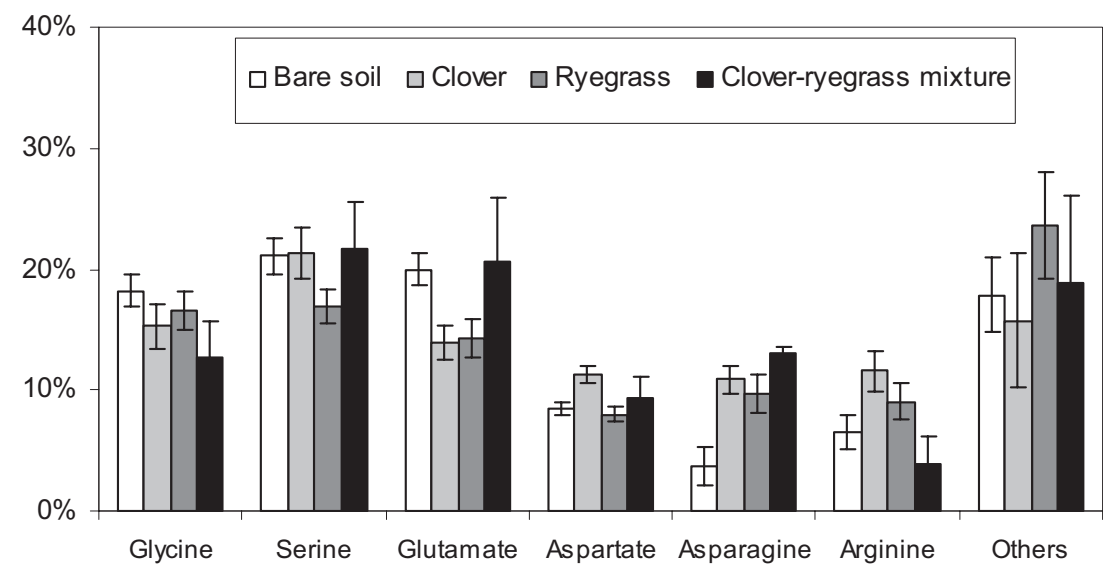

Figure 5. Individual amino acid $\mathrm{N}$ as \% of total free amino acids in the bare soil and in the rhizospheric soils of clover, ryegrass or clover ryegrass mixture. Each value is the average percentage of amino nitrogen in the soil solution at the end of the growth period. Data are means ( \pm standard error) of four independent replicates of pots of eight plants each. Amino acid profiles were close to those observed in the sterile nutrient solution, but higher proportions of asparagine were generally observed in the soil solution than in the sterile nutrient solution.

Table III. Effect of potassium nitrate $\left(\mathrm{KNO}_{3}\right)$ concentration of the nutrient solution on plant growth (expressed as mg root and shoot dry weight plant ${ }^{-1}$ ), total $\mathrm{N}$ (expressed as $\mathrm{mg} \mathrm{N}$ plant ${ }^{-1}$ ) and amount of $\mathrm{N}$ (expressed as $\mu \mathrm{g} \mathrm{N}$ plant ${ }^{-1}$ ) derived from the atmosphere for 69 day-old receiver ryegrass grown in microlysimeters. Data are means ( \pm standard error) of five independent replicates and each replicate consisted of two plants grown in individual microlysimeters. The absolute amount of $\mathrm{N}$ fixed by clover and transferred to companion ryegrass increased with $\mathrm{N}$ application. This can be related to the increase in ryegrass root growth under increasing $\mathrm{N}$ application, and subsequent increased uptake of clover-exuded compounds.

\begin{tabular}{ccccc}
\hline $\begin{array}{c}\text { Nitrate concentration of the } \\
\text { nutrient solution }\end{array}$ & $\begin{array}{c}\text { Root dry } \\
\text { weight } \\
\left(\mathrm{mg} \mathrm{plant}^{-1}\right)\end{array}$ & $\begin{array}{c}\text { Shoot dry } \\
\text { weight } \\
\left(\mathrm{mg} \mathrm{N} \text { plant }^{-1}\right)\end{array}$ & $\begin{array}{c}\text { Total N } \\
\left(\mathrm{mg} \mathrm{plant}^{-1}\right)\end{array}$ & $\begin{array}{c}\text { N derived from the atmosphere } \\
\left(\mu \mathrm{g} \mathrm{N} \mathrm{plant}^{-1}\right)\end{array}$ \\
\hline $0.1 \mathrm{mM}$ & $19 \pm 2$ & $11 \pm 1$ & $0.19 \pm 0.01$ & $33 \pm 5$ \\
$0.5 \mathrm{mM}$ & $49 \pm 2$ & $30 \pm 3$ & $0.59 \pm 0.01$ & $40 \pm 9$ \\
$1 \mathrm{mM}$ & $71 \pm 9$ & $50 \pm 2$ & $1.03 \pm 0.04$ & $22 \pm 11$ \\
$2 \mathrm{mM}$ & $142 \pm 24$ & $111 \pm 14$ & $1.98 \pm 0.02$ & $103 \pm 22$ \\
\hline
\end{tabular}

microlysimeter experiment with exudates from donor clover, and the microlysimeter system did not allow any direct contact between the root systems. These exudates contained ${ }^{15} \mathrm{NO}_{3}$ which had not been taken up by clover and $\mathrm{N}$ compounds exuded by clover roots. Control ryegrass was fed with the same nutrient solution as clover. The ${ }^{15} \mathrm{~N}$ proportion in receiver ryegrass was lower than the ${ }^{15} \mathrm{~N}$ proportion of control ryegrass, showing that $\mathrm{N}$ derived from the atmosphere fixed by clover was transferred to ryegrass through the solution.

In contrast with clover, the growth of the receiver ryegrass was highly affected by the $\mathrm{N}$ concentration of the nutrient solution: plants grown on leachate from clover grown on $2 \mathrm{mM}$ $\mathrm{KNO}_{3}$ were eight times bigger than those grown on leachate from clover grown on $0.1 \mathrm{mM} \mathrm{KNO}_{3}$ (Tab. III). Ryegrass root dry weight increased from $19 \mathrm{mg}$ for the $0.1 \mathrm{mM}$ treatment to $142 \mathrm{mg}$ for the $2 \mathrm{mM}$ treatment. Although the percentage of $\mathrm{N}$ derived from the atmosphere in ryegrass decreased with increasing concentration of $\mathrm{N}$ in the nutrient solution (from $17.8 \%$ for $0.1 \mathrm{mM}$ treatment to $5.2 \%$ for $2 \mathrm{mM}$ treatment), the absolute amount of $\mathrm{N}$ fixed by clover and transferred to companion ryegrass increased from $33 \mu \mathrm{g} \mathrm{N}$ plant $^{-1}$ for the $0.1 \mathrm{mM}$ treatment to $103 \mu \mathrm{g} \mathrm{N}$ plant $^{-1}$ for the $2 \mathrm{mM}$ treatment
(Tab. III). We observed a linear correlation between ryegrass root dry weight (g dry weight plant ${ }^{-1}$ ) and amounts of $\mathrm{N}$ derived from the atmosphere and transferred to ryegrass ( $\mathrm{mg} \mathrm{N}$ plant $\left.^{-1}\right)\left(r^{2}=0.642, P<0.05\right)$. The receiver ryegrass had access to only one-half of the clover exudates, because the other half was kept for analysis: therefore, the potential $\mathrm{N}$ transfer is double that measured.

Despite the decrease in atmospheric $\mathrm{N}$ in clover with increasing nitrate concentration of the nutrient solution, we found that increasing $\mathrm{N}$ input can lead to an increase in $\mathrm{N}$ derived from the atmosphere and transferred to ryegrass, expressed per plant. In a previous study with two-month-old ryegrass and clover grown in the same pots, we measured amounts of $\mathrm{N}$ transferred between species in the same order of magnitude and with similar effects of $\mathrm{N}$ application (Paynel et al., 2001). Høgh-Jensen and Schjoerring (1997) and Elgersma et al. (2000) also noted an increase in $\mathrm{N}$ transfer with increasing $\mathrm{N}$ application, for one- and two-year-old plants grown in mixture, expressed in $\mathrm{g}$ per ha. The increase in atmospheric $\mathrm{N}$ transfer from clover to ryegrass cannot be explained by an increase in $\mathrm{N}$ rhizodeposition, as shown by both the axenic experiment and the soil experiment. Ammonium 
concentration in receiver ryegrass exudates decreased with the nitrate application rate (Fig. 1), while ammonium concentration of clover exudates provided to ryegrass was independent of nitrate application. This demonstrates that nitrate application stimulates ryegrass uptake of ammonium released by clover. Ryegrass can take up ammonium and amino acids released by clover in microlysimeters (Paynel and Cliquet, 2003) and the uptake of ammonium and glycine by ryegrass and other grasses in field conditions is now clearly demonstrated (Streeter et al., 2000; Weigelt et al., 2005). The highest root dry weight was observed in the high $\mathrm{N}$ treatment and could result in a more efficient uptake of ammonium exuded by clover, as shown in the axenic experiment. Our data show that the stimulation of $\mathrm{N}$ transfer by nitrate application could be the result of a stimulation of root development by $\mathrm{N}$.

\section{CONCLUSION}

Our results show three major points. First, we found that $\mathrm{N}$ application drastically reduced $\mathrm{N}$ fixation by clover grown axenically in sand or in soil-filled pots. This reduction in $\mathrm{N}$ fixation brought about an increase in ammonium content and a decrease in amino acid content of clover root tissues, but had no effect on the amount of ammonium and amino acids exuded by clover. This result suggests that net exudation of ammonium and most of the amino acids is not dependent only on the concentration gradient between root tissue and root bathing solution, as generally admitted. Second, in soil, the increase in $\mathrm{N}$ fixation resulted in an increase in ammonium concentration in soil, suggesting that $\mathrm{N}$ fixation could be a source of ammonium for soil. Here, we observed the recurrent presence of some amino acids, glycine, serine and glutamate, both in axenic exudates and in soil. These results show a link between $\mathrm{N}$ fixation and $\mathrm{N}$ compound exudation. Third, the increase in $\mathrm{N}$ transfer from clover to ryegrass observed in the hydroponic study could be explained by a more efficient $\mathrm{N}$ uptake by ryegrass, as ryegrass root dry weight increased with $\mathrm{N}$ concentration of the nutrient solution. This resulted in a better exploration of the sand or the soil by ryegrass and a better access to different available $\mathrm{N}$ sources, including the $\mathrm{N}$ compounds exuded by clover.

Acknowledgements: The authors wish to thank M.P. Bataillé and A. Bré for skilful technical assistance. We are grateful to P.J. Murray for critical review of the manuscript.

\section{REFERENCES}

Benizri E., Courtade A., Guckert A. (1995) Fate of two microorganisms in maize simulated rhizosphere under hydroponic and sterile conditions, Soil Biol. Biochem. 27, 71-77.

Brophy L.S., Heichel G.H. (1989) Nitrogen release from roots of alfalfa and soybean grown in sand culture, Plant Soil 116, 77-84.

Boller B.C., Nösberger J. (1987) Symbiotically fixed nitrogen from field grown white and red clover mixed with ryegrass at low level of ${ }^{15} \mathrm{~N}$ fertilization, Plant Soil 104, 219-226.
Deutsch B., Kahle P., Voss M. (2006) Assessing the source of nitrate pollution in water using stable $\mathrm{N}$ and $\mathrm{O}$ isotopes, Agron. Sustain. Dev. 26, 263-267.

Elgersma A., Schlepers H., Nassiri M. (2000) Interactions between perennial ryegrass (Lolium perenne L.) and white clover (Trifolium repens L.) under contrasting nitrogen availability: productivity, seasonal patterns of species composition, $\mathrm{N}_{2}$ fixation, $\mathrm{N}$ transfer and $\mathrm{N}$ recovery, Plant Soil 221, 281-299.

Garg N., Geetanjali (2007) Symbiotic nitrogen fixation in legume nodules: process and signaling. A review, Agron. Sustain. Dev. 27, 5968.

Grayston S.J., Wang S., Campbell C.D., Edwards A.C. (1998) Selective influence of plant species on microbial diversity in the rhizosphere, Soil Biol. Biochem. 30, 369-378.

Hertenberger G., Zampach P., Bachmann G. (2002) Plant species affect the concentration of free sugars and free amino acids in different types of soil, J. Plant Nutr. Soil Sci. 165, 557-565.

Hertenberger G., Wanek W. (2004) Evaluation of methods to measure differential ${ }^{15} \mathrm{~N}$ labeling of soil and root $\mathrm{N}$ pools for studies of root exudation, Rapid Commun. Mass Spectrom. 18, 2415-2425.

Høgh-Jensen H., Schjoerring J.K. (1997) Interaction between white clover and ryegrass under contrasting nitrogen availability: $\mathrm{N}_{2}$ fixation, $\mathrm{N}$ fertilizer recovery, $\mathrm{N}$ transfer and water-use efficiency, Plant Soil 197, 187-199.

Høgh-Jensen H., Schjoerring J.K. (2001) Rhizodeposition of nitrogen by red clover, white clover and ryegrass leys, Soil Biol. Biochem. 33, 439-448.

Johansen A., Jensen E.S. (1996) Transfer of N and P from intact or decomposing roots of pea to barley inter connected by an arbuscular mycorrhizal fungus, Soil Biol. Biochem. 28, 73-81.

Jones D.L, Darrah P.R. (1994) Amino acid influx at the soil-root interface of Zea mays L. and its consequences in the rhizosphere, Plant Soil $163,1-12$.

Jones D.L., Owen A.G., Farrar J. (2002) Simple method to enable the high resolution determination of total free amino acids in soil solutions and soil extracts, Soil Biol. Biochem. 34, 1893-1902.

Jones D.L., Hodge A., Kuzyakov Y. (2004) Plant and mycorrizal regulation of rhizodeposition, New Phytol. 163, 459-480.

Kielland K. (1995) Landscape pattern of free amino acids in Artic tundra soils, Biogeochemistry $31,85-98$.

Ledgard S.F., Steele K.W. (1992) Biological nitrogen fixation in mixed legume-grass pastures, Plant Soil 141, 137-153.

Lesuffleur F., Paynel F., Bataillé M.P., Le Deunff E., Cliquet J.B. (2007) High proportions of glycine and serine in root exudates of six different species result from hight efflux rates, Plant Soil 294, 235-246.

Lipson D.A., Raab T.K., Schmidt S.K., Monson R.K. (1999) Variation in competitive abilities of plants and microbes for specific amino acids, Biol. Fert. Soils 29, 257-261.

Lipson D.A., Raab T.K., Schmidt S.K., Monson R.K. (2001) An empirical model of amino acid transformations in an alpine soil, Soil Biol. Biochem. 33, 189-198.

Murashige T., Skoog F. (1962) A revised medium for rapid growth and bio assays with tobacco tissue cultures, Physiol. Plant. 15, 473-497.

Näsholm T., Huss-Danell K., Högberg P. (2001) Uptake of glycine by field-grown wheat, New Phytol. 150, 59-63.

Nguyen C. (2003) Rhizodeposition of organic C by plants: mechanisms and control, Agronomie 23, 375-396.

Paynel F., Murray P.J., Cliquet J.B. (2001) Root exudates: a pathway for short-term N transfer from clover to ryegrass, Plant Soil 229, $235-243$

Paynel F., Cliquet J.B. (2003) N transfer from white clover to perennial ryegrass, via exudation of nitrogenous compounds, Agronomie 23, 503-510. 
Phillips D.A., Fox T.C., King M.D., Bhuvaneswari T.V., Teuber L.R. (2004) Microbial products trigger amino acid exudation from plant roots, Plant Physiol. 136, 2887-2894.

Rogers J.B., Laidlaw A.S., Christie P. (2001) The role of arbuscular mycorrhizal fungi in the transfer of nutrients between white clover and perennial ryegrass, Chemosphere 42, 153-159.

Rroço E., Kosegarten H., Mengel K. (2002) Importance of plasmalemma $\mathrm{H}^{+}$-ATPase activity for $\mathrm{N}$ losses from intact roots of spring wheat (Triticum aestivum L.), Eur. J. Agron. 16, 187-196.

Shepherd T., Davies H.V. (1994) Pattern of short-term amino acid accumulation and loss in the root zone of liquid-cultured forage rape, Plant Soil 158, 99-109.

Soussana J.F., Hartwig U.A. (1996) The effect of elevated $\mathrm{CO}_{2}$ on symbiotic $\mathrm{N}_{2}$ fixation: a link between carbon and nitrogen cycles in grassland ecosystems, Plant Soil 187, 321-332.

Streeter T.C., Bol R., Bardgett R.D. (2000) Amino acids as a nitrogen source in temperate upland grasslands: the use of dual labelled $\left({ }^{13} \mathrm{C}\right.$, ${ }^{15} \mathrm{~N}$ ) glycine to test for direct uptake by dominant grasses, Rapid Commun. Mass Spectrum. 14, 1351-1355.

Svenning M.M., Juntilla O., Macduff J.H. (1996) Differential rates of inhibition of $\mathrm{N}_{2}$ fixation by sustained low concentrations of $\mathrm{NH}_{4}^{+}$and $\mathrm{NO}_{3}^{-}$in northern ecotypes of white clover (Trifolium repens L.), J. Exp. Bot. 47, 729-738.
Ta T.C., Faris M.A. (1987) Species variation in the fixation and transfer of nitrogen from legumes to associated grasses, Plant Soil 98, 265-274.

Ta T.C., MacDowall D.H., Faris M.A. (1986) Excretion of nitrogen assimilated from $\mathrm{N}_{2}$ fixed by nodulated roots of alfalfa (Medicago sativa), Can. J. Bot. 64, 2063-2067.

Thornton B., Robinson D. (2005) Uptake and assimilation of nitrogen from solutions containing multiple N sources, Plant Cell Environ. $28,813-821$.

Thomas B.D., Bowman W.D. (1998) Influence of $\mathrm{N}_{2}$-fixing Trifolium on plant species composition and biomass production in alpine tundra, Oecologia 115, 26-31.

Umar A.S., Iqbal M. (2007) Nitrate accumulation in plants, factors affecting the process, and human health implications. A review, Agron. Sustain. Dev. 27, 45-57.

Volk R.J. (1995) ${ }^{15} \mathrm{~N}$ assays of ammonium cycling in maize roots, in: INRA (Les Colloques, $\mathrm{n}^{\circ}$ 70) (Ed.), Utilisation des isotopes stables pour l'étude du fonctionnement des plantes, Paris, France, pp. $175-182$.

Weigelt A., Bol R., Bardgett R.D. (2005) Preferential uptake of soil nitrogen forms by grassland plant species, Oecologia 142, 627-635.

White J., Prell J., James E.K., Poole P. (2007) Nutrient sharing between symbionts, Plant Physiol. 144, 604-614. 